\title{
MODAL SOSIAL PADA USAHA BAGAN DI DESA TATELI WERU KECAMATAN MANDOLANG KABUPATEN MINAHASA PROVINSI SULAWESI UTARA
}

\author{
Fahmi Fokatea'; Jardie A. Andaki²; Djuwita R.R. Aling2; \\ 1)Mahasiswa Fakultas Perikanan dan IImu Kelautan Universitas Sam Ratulangi Manado \\ 2)Staff Pengajar Fakultas Perikanan dan IImu Kelautan Universitas Sam Ratulangi Manado \\ Koresponden email : fahmifokatea@gmail.com
}

\begin{abstract}
The purpose of this research is to identify social capital that plays a role in developing business charts in Tateli Weru Village, Mandolang District, Minahasa Regency, North Sulawesi Province. The method used is a survey for primary data or direct observation. Respondents in this study were fishermen who had a fishing gear, which amounted to 12 respondents. Data analysis will be used in this study, namely descriptive analysis. Based on the results and discussion, it can be concluded: 1) social capital in the chart fishermen group in Tateli Weru Village, namely trust, norms, network and coorperative, and 2) trust (trust) ), norms, networks and coorperatives in synergy with each other in groups of fishermen, forming a social interaction of mutual symbiosis in the development of capture fisheries business related to access to capital resources, human resources and the sale of catches.
\end{abstract}

Keywords: Chart Fishermen, Social Capital, Business Development

\begin{abstract}
Abstrak
Tujuan penelitian ini, yaitu mengidentifikasi modal sosial yang berperan pada pengembangan usaha bagan di Desa Tateli Weru Kecamatan Mandolang Kabupaten Minahasa Provinsi Sulawesi Utara. Metode yang digunakan adalah survei untuk data primer atau pengamatan secara langsung. Responden dalam penelitian ini ialah nelayan yang memiliki alat tangkap bagan, yaitu berjumlah 12 responden. Analisis data yang akan digunakan dalam penelitian ini, yaitu analisis deskriptif. Berdasarkan hasil dan pembahasan maka dapat disimpulkan: 1) modal sosial yang ada pada kelompok nelayan bagan di Desa Tateli Weru, yaitu kepercayaan (trust), norma (norm), jaringan (network) dan kerjasama (coorperative), dan 2) kepercayaan (trust), norma (norm), jaringan (network) dan kerjasama (coorperative) bersinergi satu dengan lainnya dalam kelompok nelayan, membentuk suatu interaksi sosial simbiosis mutualis dalam pengembangan usaha perikanan tangkap bagan terkait akses sumberdaya modal, sumberdaya manusia dan penjualan hasil tangkapan.
\end{abstract}

Kata Kunci : Nelayan Bagan, Modal Sosial, Pengembangan Usaha

\section{PENDAHULUAN}

Perikanan tangkap merupakan bidang usaha yang banyak dilakukan untuk memperoleh ikan salah salah satunya ialah bagan apung. Bagan apung merupakan satu kontruksi jaring berbentuk segi empat dan menggunakan dua buah tiang sebagai penggantung dan pembuka jaring, bagian atas jaring diberi alat pelampung dan bagian sebelah bawah di ikat pemberat.Bagan merupakan salah satu jenis alat tangkap yang digunakan nelayan di tanah air untuk menangkap ikan pelagis kecil, pertama kali diperkenalkan oleh nelayan Bugis-Makassar sekitar tahun 1950-an. Selanjutnya dalam waktu relatif singkat alat tangkap tersebut sudah dikenal di seluruh Indonesia. Bagan dalam perkembangannya telah mengalami banyak perubahan baik bentuk maupun ukuran yang dimodifikasi sedemikian rupa sehingga sesuai dengan daerah penangkapannya (Sudirman et al., 2011).

Salah satu desa yang memiliki nelayan dengan alat tangkap bagan ialah Desa Tateli Weru Kecamatan Mandolang Kabupaten Minahasa Provinsi Sulawesi Utara. Desa ini memiliki 23 nelayan bagan yang menjalankan usaha untuk menengkap ikan (Profil Desa Tateli Weru, 2017). Alat tangkap bagan dalam pengadaannya membutuhkan biaya yang cukup besar. Akan teratasi karena kerjasama, tolong menolong dan gotong royong. Biaya yang dimaksud ialah biaya untuk membuat alat tangkap bagan. Besarnya biaya ini membutuhkan kerja sama 
dalam bentuk interaksi sosial antara nelayan maupun antara pemilik modal.

Kemampuan nelayan untuk terlibat dalam satu hubungan sosial merupakan salah satu bentuk modal sosial yang harus dimiliki oleh nelayan terlebih khusus nelayan bagan. Modal sosial merupakan serangkaian arti nilai dan norma informal yang dimiliki bersama di antara para anggota suatu kelompok yang memungkinkan terjalinnya kerja sama di antara mereka (Fukuyama, 2002). Berdasarkan latar belakang tersebut maka perlu dilakukan penelitian guna mengkaji tentang modal sosial pada usaha bagan di Desa Tateli Weru Kecamatan Mandolang Kabupaten Minahasa Provinsi Sulawesi Utara.

\section{Rumusan Masalah}

Adapun rumusan masalah dalam penelitian ini, yaitu bagaimana modal sosial berperan pada pengembangan usaha bagan di Desa Tateli Weru Kecamatan Mandolang Kabupaten Minahasa Provinsi Sulawesi Utara.

\section{Tujuan dan Kegunaan}

Tujuan dari penelitiancini, yaitu mengidentifikasi modal sosial yang berperan pada pengembangan usaha bagan di Desa Tateli Weru Kecamatan Mandolang Kabupaten Minahasa Provinsi Sulawesi Utara.

\section{Tempat dan Waktu Penelitian}

Penelitian ini dilaksanakandi Desa Tateli Weru Kecamatan Mandolang Kabupaten Minahasa Provinsi Sulawesi Utara. Waktu yang diperlukan dalam melaksanakan penelitian mulai dari konsultasi, observasi lapangan, penyusunan Rencana Kerja Penelitian, pengumpulan data, analisis data, penulisan laporan akhir sampai pada ujian, kurang lebih 5 bulan, yaitu dari bulan Januari - Mei 2019.

\section{METODE PENELITIAN}

Metode penelitian pada dasarnya merupakan cara ilmiah untuk mendapatkan data dengan tujuan dan kegunaan tertentu (Sugiyono, 2001). Metode yang digunakan dalam penelitian ini adalah studi kasus menurut Faisal (1995), merupakan tipe pendekatan yang penelaahannnya pada satu kasus dilakukan secara intensif mendalam, mendetail, dan komprehensif.

\section{Teknik Pengambilan Sampel}

Sampel $₫$ adalah bagian dari jumlah karakteristik yang dimiliki oleh populasi tersebut (Sugiyono, 2012).Pengambilan sampel untuk dijadikan responden dilakukan dengan teknik purposive sampling. Menurut Sugiyono (2010),purposive sampling merupakan teknik untuk menentukan sampel penelitian dengan beberapa perkembangan tertentu yang bertujuan data yang diperoleh nantinyalebih representatif.

\section{Metode Pengumpulan Data}

Metode yang digunakan adalah survei untuk data primer atau pengamatan secara langsung. Metode survei merupakan suatu praktek yang dilakukan dengan cara mengumpulkan, menyidik dan menafsirkan data secara umum sebagai apa adanya yang tersedia di lapangan, khususnya diDesa Tateli Weru, Kecamatan Mandolang, Kabupaten Minahasa Provinsi Sulawesi Utara.

Responden dalam penelitian ini ialah nelayan yang memiliki alat tangkap bagan. Jenis bagan yang adadi Desa Tateli Weru, yaitu bagan apung. Jumlah nelayan yang memiliki alat tangkap 
bagan berjumlah 23 orang (Profil Desa Tateli Weru, 2017). Berdasarkan total responden nelayan yang memiliki alat tangkap bagan di Desa Tateli Weru, akan diambil $50 \%$, yaitu berjumlah 12 responden.

Observasi dan wawancara akan dilakukan guna mengungkapkan modalmodal sosial yang berperan pada pengembangan usaha bagan. Metode observasi merupakan metode pengumpulan data yang dilakukan dengan cara mengamati dan mencatat secara sistematik gejala-gejala yang diselidiki (Supardi, 2006). Untuk melengkapi cara memperoleh data, penulis mempergunakan metode observasi nonpartisan yaitu mengamati mencari data dari berbagai fakta yang ada hubungannya dengan permasalahan (Walgito, 2010), observasi adalah penyelidikan secara sistematis dan disengaja melalui pengamatan ke arah kejadian-kejadian yang spontan pada saat kejadian terjadi dengan menggunakan alat indera sebagai pengamat.

Metode wawancara adalah proses tanya jawab dalam penelitian yang berlangsung secara lisan dimana dua orang atau lebih bertatap muka mendengarkan secara langsung informasi-informasi atau keteranganketerangan (Supardi, 2006). Pendapat ahli Jain mengatakan bahwa wawancara adalah percakapan yang dilakukan oleh dua orang atau lebih yaitu wawancara yang akan mengajukan pertanyaan dan orang yang akan diwawancarai yang akan memberikan jawaban atas pertanyaan yang akan diajukan dengan tatap muka maupun telepon. Wawancara yang juga dikenal dengan interview adalah pengumpulan data dengan mengajukan pertanyaan secara langsung oleh pewawancara kepada responden dan jawaban responden dicatat atau direkam (Moleong, 2005).

Sedangkan metode kuesioner merupakan teknik pengumpulan data yang dilakukan dengan cara memberi seperangkan pertanyaan atau pertanyaan tertulis kepada responden untuk dijawab (Sugiono, 2012).

\section{Analisis Data}

Analisis data yang akan digunakan dalam penelitian ini, yaitu analisis deskriptif. Analisis deskriptif merupakan analisis data dengan cara menggambarkan cdata yang telah terkumpul sebagaimana adanya tanpa membuat kesimpulan umum atau generalisasi. Menurut (Widi, 2010), analisis deskriptif merupakan penelitian yang mencoba untuk memberikan gambaran secara sistematis tentang situasi, permasalahan, phenomena, layanan atau program.

\section{HASIL DAN PEMBAHASAN}

\section{Modal Sosial pada Usaha Bagan}

Usaha yang dilakukan nelayan bagan di Desa Tateli Weru ini juga tidak menetap disebabkan karena usaha mereka sangat tergantung pada kondisi alam yang tidak menentu, maka hasil tangkapannyapun tidak menentu. Kerja sebagai nelayan bagan bukanlah merupakan usaha usaha tunggal, artinya seorang nelayan bagan tidak sematamata berusaha/bermata pencaharian sebagai nelayan saja jika nelayan bagan sudah mendarat pada pagi hari, sepanjang siang sama sore ketika persiapan melaut sudah dikerjakannya, nelayan beraktifitas dibidang lain. Demikian halnya ketika cuaca sedang buruk dan tidak memungkinkan mereka melaut, nelayan bagan beraktivitas pada bidang lain di luar usaha penangkapan ikan. 
Modal sosial seringkali digunakan dalam usaha pencapaian tujuan, salah satunya untuk menjaga kelansungan usaha. Begitu pula juga dengan usaha bagan di Desa Tateli Weru. Modal sosial yang ada pada usaha bagan merujuk pada kepercayaan, norma dan jaringan yang berpotensi pada kelangsungan usaha bagan. Modal sosial pada usaha perikanan tangkap bagan yang dibahas terkait eksistensi usaha bagan, yaitu kepercayaan (trust), norma, jaringan (network), dan kerjasama.

\section{Kepercayaan (trust)}

Kepercayaan merupakan unsur paling penting yang membentuk unsurunsur modal sosial lainnya. Trust sebagai kata benda berarti kepercayaan, keyakinan atau juga rasa percaya. Sedangkan trust dalam kata kerja berarti proses mempercayai sesuatu yang jelas sasaranya. Menurut Lawang (2005), trust adalah hubungan antar manusia dua pihak atau lebih yang mengandung harapan yang menguntungkan salah satu atau kedua belah pihak.

Dalam melaksanakan kegiatan penangkapan ikan dengan menggunakan bagan, hail mana lokasi diletaknya bagan berada cukup jauh dari daratan, maka dibutuhkan hubungan sosial yang baik antara pemilik dan pekerja, dan atau hubungan yang baik antara sesama pengusaha penangkapan ikan dengan bagan. Misalnya kebersamaan dalam saling menjaga dan mengawasi bagan secara bersamasama, dari pencurian ikan dari orang luar maupun orang dalam Desa Tateli Weru. Demikian pula saling menjaga agar bagan yang ada tidak dirusak oleh orang-orang yang tidak bertanggung jawab. Sebab pernah kejadian pencurian dan pengrusakan terjadi apakah karena faktor kecemburuan dan faktor persaingan.

Hasil wawancara dengan responden bahwa mereka saling menjaga bagan bila ditinggalkan pemilik atau pekerja yang pulang ke rumah. Dalam hal ini dapat dijelaskan bahwa partisipasi untuk saling menjaga terbentuk karena adanya saling percaya satu dengan lainnya karena terikat dalam hubungan sosial yang baik dan saling menguntungkan. Partisipasi saling menjaga akan bersimbiosis mutualis, karena tidak selamanya kita akan mampu menjaga bagan kita sepanjang waktu, dikarenakan berbagai keperluan lain juga harus memaksa kita meninggalkan bagan dan mempercayakan keberadaannya kepada orang lain, demikian sebaliknya.

Munculnya kepercayaan satu dengan lainnya tidak terlepas dari kegiatan-kegiatan sosial, keagamaan yang diikuti. Sebanyak 100\% responden terlibat dalam kegiatan keagamaan (Kaum Bapa/lbu, Kolom dan kegiatan lainnya yang sering di ikuti Seperti Paskah, Ibadah rumah tangga, Paduan suara PKB dan WKI dan Kelompok Ibadah). Pada kegiatan-kegiatan inilah terbentuk interaksi sosial membicarakan dan membahas permasalahanpermasalahan dari usaha perikanan tangkap bagan. Interaksi-interaksi sosial ini dapat melahirkan kesepakatankesepakatan untuk saling menjaga dan mengawasi keberadaan bagan masingmasing dan antar kelompok usaha penangkapan ikan dengan bagan. Demikian pula baik pemilik dan pekerja akan saling berinteraksi dan mengkompromikan berbagai hal terkait saling percaya untuk kepentingan bersama.

Kompromi-kompromi yang tercipta dalam pertemuan-pertemuan 
keagamaan ini dengan sendirinya akan membatasi pekerja yang kurang jujur menjadi lebih jujur dalam melaporkan hasil tangkapan dan atau hasil penjualan, karena adanya mekanisme saling mengawasi. Dengan demikian usaha perikanan tangkap bagan di Tateli Weru dalam berjalan dengan baik dan aman. Sebagaimana yang dijelaskan Fukuyama (2002), bahwa kepercayaan adalah harapan yang tumbuh di dalam sebuah masyarakat yang ditunjukan oleh adanya prilaku jujur, teratur, dan kerjasama berdasarkan norma-norma yang dianut bersama. Kemudian mencatat bahwa dalam masyarakat yang memiliki tingkat kepercayaaan tinggi, aturan-aturan sosial cenderung bersifat positif, hubungan-hubungan juga bersifat kerjasama

\section{Norma (norm)}

Norma adalah aturan-aturan, petunjuk-petunjuk, tidak dilaksanakan akan merugikan diri sendiri atau merugikan orang lain (Lawang, 2005). Selain itu dikatakan bahwa norma tidak dapat dipisahkan dari jaringan (network) dan kepercayan (trust).

Pada usaha bagan di Desa Tateli Weru, terdapat aturan aturan yang mengatur usaha bagan agar berjalan dengan semestinya. Aturan-aturan yang ada sifatnya tidak tertulis. Misalnya perjanjian tidak tertulis antara pemiliki bagan dan pembeli, hal mana kesepakatan jual beli dilakukan menurut perjanjian. Kapal penangkap cakalang (huhate) sebagai pembeli hasil tangkapan bagan (ikan teri hidup) sudah melakukan perjanjian pembelian pada pemilik bagan. Pada musim ikan teri juga merupakan musim penangkapan ikan cakalang, maka berdasarkan perjanjian yang sudah dibuat, maka kapal huhate akan mempersiapkan semua kebutuhan untuk penangkapan ikan cakalang, sedangkan untuk umpan (ikan teri hidup), akan dibeli pada pemilik bagan yang ada di Desa Tateli Weru.

Pelanggaran pada norma perjanjian pembelian akan berakibat pada tidak akan dipercaya lagi untuk pembelian yang akan datang. Jika hal ini terjadi maka kerugian akan dialami oleh kedua pihak. Pada pihak pembeli yang sudah siap untuk turun melaut akan kehilangan kesempatan untuk melaut karena ketidakadaan umpan ikan teri hidup, sedangkan pada pihak penjual ikan dari hasil tangkapan bagan akan kehilangan pembeli pada waktu akan datang.

Aturan juga diterapkan atau disepakati tentang pembayaran hasil tangkapan dilakukan pada saat ikan dimuat di kapal penangkap/huhate. Kesepakatan ini secara tidak tertulis menjadi aturan yang tersirat ketika hasil tangkapan telah dipindah ke kapal huhate, dimana ikan teri benar-benar masih hidup ketika dipindahkan ke kapal huhate.

Syarat harus hidup ikan teri ketika dipindahkan ke kapal huhate, telah menjadi kesepakatan, ketentuan, dan atau syarat mutlak transaksi dapat diteruskan atau tidak. Kapal huhate dalam operasi penangkapan ikan membutuhkan umpan hidup (ikan teri) guna menarik kumpulan ikan (schooling fish) untuk dapat selama mungkin berada dekat dengan kapal, untuk selanjutnya pemancing yang menggunakan joran menangkap kumpulan cakalang. Ketergantungan dan kebutuhan inilah sebabnya mengapa, syarat ikan teri hasil tangkapan bagan harus dalam keadaan hidup dan kuat setelah dipindahkan ke kapal huhate.

Norma atau aturan-aturan ini secara alamiah harus disepakati atau 
dikompromikan secara bersama-sama agar kedua belah pihak mendapatkan keuntungan. Pada pihak produsen, pemilik bagan akan mendapat keuntungan dengan terjualnya ikan hasil tangkapan, sedangkan pada sisi konsumen, pemilik kapal huhate mendapatkan kesempatan untuk menangkap cakalang. Kondisi simbiosis muatis ini, sama dengan yang diungkapkan Suharto (2014), bahwa norma terdiri dan pemahamanpemahaman, nilai-nilai, harapan-harapan dan tujuan-tujuan yang diyakini dan dijalankan bersama oleh sekelompok orang. Norma-norma dibangun dan berkembang berdasarkan sejarah kerjasama dimasa lalu dan diterapkan untuk mendukung iklim kerjasama.

\section{Jaringan (network)}

Jaringan memiliki peran penting di dalam menjaga keberlangsungan usaha bagan. Kegiatan yang dilakukan usaha penangkapan ikan dengan bagan Di dalam menjaga keberlangsungan usaha, jaringan sangat perlu untuk dijaga. Keberadaan jaringan sangat penting, seperti informasi tentang kebutuhan ikan hasil tangkapan bagan. Jaringan informasi personal dari orang per orang dapat membuka peluang permintaan dan kebutuhan dari konsumen.

Pada Kapal huhate yang merupakan konsumen utama hasil tangkapan bagan di Desa Tateli Weru, maka jaringan informasi tentang kesiapan hasil tangkap dan kesesuaian operasi penangkapan merupakan kunci keberhasilan penjualan ikan hasil tangkapan bagan. Ikan teri yang harus dalam keadaan hidup menjadi tantangan atau faktor pembatas usaha ini, hal mana jika kondisi ikan teri yang tertangkap terlalu lama di dalam jaring maka akan dapat melemahkan dan bahkan dapat menyebabkan kematian pada ikan teri. Pada kondisi ini maka, harga ikan teri akan menjadi rendah karena hanya dapat dijual pada konsumen rumah tangga dan atau diawetkan dengan cara pengeringan. Sebaliknya bila dalam keadaan hidup akan memiliki harga yang lebih mahal. Dalam hal ini network berperan penting dalam pengembangan usaha perikanan tangkap bagan terkait akses sumberdaya pasar untuk penjualan hasil tangkapan, hal ini sesuai dengan hasil penelitian Louhenapessy dkk., (2017) yang menyimpulkan hal yang sama terkait implikasi modal sosial.

Jaringan yang luas pada pengusaha bagan juga berpengaruh pada informasi tenaga kerja yang sesuai. Informasi tentang tenaga kerja dan karakteristiknya dapat diketahui dari keeratan jaringan informasi. Pada informasi yang terpercaya, kebutuhan tenaga kerja dapat disesuaikan dengan cara kerja, jam kerja dan upah yang menguntungkan baik kepada pekerja maupun kepada pemiliki usaha bagan.

Masyarakat yang sehat termasuk kelompok nelayan bagan, cenderung memiliki jaringan-jaringan sosial yang kokoh. Orang mengetahui dan bertemu dengan orang lain. Mereka kemudian membangun interelasi yang kental, baik bersifat formal maupun informal. Putnam berargumen bahwa jaringan-jaringan sosial yang erat akan memperkuat perasaan kerjasama para anggotanya serta manfaat-manfaat dan partisipasinya itu.

\section{Kerjasama (coorperative)}

Kerjasama ditimbulkan dari adanya kebersamaan dan rasa memiliki latar belakang yang sama. Kerjasama harus dikembangkan karena akan 
menimbulkan efek keberhasilan pada sesama anggota.

Pada nelayan yang mengusahakan alat tangkap bagan di Desa Tateli Weru, kerjasama sangat dan mutlak diperlukan. Misalnya pada pembuatan rumah bagan, maka sikap dan perilaku gotong royong dapat menyelesaikan rumah bagan lebih cepat. Demikian pula ketika rumah bagan akan di bawah ke laut, maka kebersamaan untuk mengangkat rumah bagan menuju pantai lalu ke laut dapat berhasil dilakukan.

Demikian pula kerjasama dalam menjaga keamanan rumah bagan di tengah lautan menjadi penting, karena tidak selamanya pemilik maupun pekerja tetap selalu berada di rumah bagan. Pada kondisi tanpa pengawasan ini, maka sesama anggota kelompok nelayan bagan akan berpatisipasi menjaga secara bersama-sama, buka saja menjaga dari orang-orang yang tidak bertanggung jawab, namun juga menjaga unit penangkapan bagan dari acaman arus dan gelombang atau faktor alam lainnya.

Hasil pembahasan ini menggambarkan bahwa modal sosial baik itu keperacayaan (trust), norma, jaringan dan kerjasama akan bersinergi dan saling menguntungkan (simbiosis mutualis). Gambaran tentang modal sosial dan pengaruhnya pada usaha perikanan tangkap bagan, dapat dilihat pada gambar berikut.

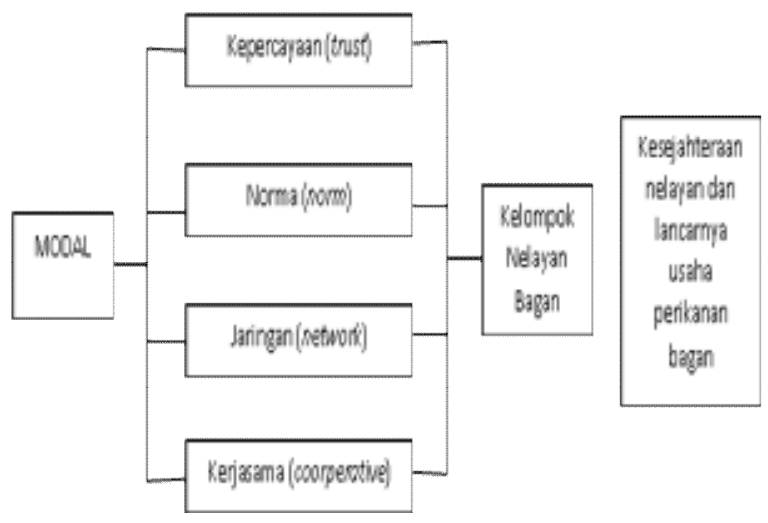

Bagan Modal Sosial dan Pengaruhnya pada Usaha Perikanan Tangkap Bagan di Desa Tateli Weru.

Bagan ini menunjukkan bahwa kelompok nelayan terbentuk karena adanya modal sosial. Modal sosial dalam bentuk kepercayaan (trust), norma (norm), jaringan (network), dan kerjasama (coorperative), merupakan satu bingkai dalam membentuk kelompok nelayan.

Partisipasi anggota kelompok untuk saling mempercayai, taat terhadap aturan (norma), berada dalam satu jaringan, dan selalu bekerja sama dalam mencapai tujuan merupakan kunci kesejahteraan dan lancarnya usaha perikanan tangkap bagan, khususnya di Desa Tateli Weru.

\section{KESIMPULAN DAN SARAN Kesimpulan}

Berdasarkan hasil dan pembahasan maka dapat disimpulkan:

Modal sosial yang ada pada kelompok nelayan bagan di Desa Tateli Weru, yaitu kepercayaan (trust), norma (norm), jaringan (network) dan kerjasama (coorperative)

Kepercayaan (trust), norma (norm), jaringan (network) dan kerjasama (coorperative) bersinergi satu dengan lainnya dalam kelompok nelayan, membentuk suatu interaksi sosial simbiosis mutualis dalam 


\section{pengembangan usaha perikanan tangkap bagan terkait akses sumberdaya modal, sumberdaya manusia dan penjualan hasil tangkapan.}

\section{Saran}

Saran yang diberikan dari hasil penelitian ini, yaitu: hubungan sosial dan interaksi sosial yang membentuk kelompok perlu diberikan wadah formal, misalnya koperasi nelayan atau kelompok nelayan yang berbadan hukum.

\section{DAFTAR PUSTAKA}

Anam, N., 2013. Pedoman Praktik Pembelajaran Microteaching. Surakarta: Laboratorium FKIP Universitas Muhammadiyah Surakarta.

Fukuyama, F., 2002. Trust; Kebijakan Sosial dan Penciptaan Kemakmuran, Yogyakarta: Penerbit Qalam.

Ha, Seong-Kyu, 2010. Housing, Sosial Capital and Community development in Seoul. Cities 27 (2010).

Hasbullah, J., 2006. Sosial Capital (Menuju Keunggulan Budaya Manusia Indonesia) Jakarta: MR United Press.

Kementerian Kelautan dan Perikanan, 2013. Data Informasi Peningkatan Budidaya lkan Nila di Indonesia. Sumber : www.KKP.go.id (20 Februari 2013).

Khairuman dan Amri, 2013. Budi Daya Ikan. Jakarta: Agromedia.

Kusnadi, 2009. Keberdayaan Nelayan dan Dinamika Ekonomi Pesisir. Pusat Penelitian wilayah pesisir dan pulau-pulau kecil. Jember: lembaga penelitian universitas jember.

Lawang, R.M.Z., 2005. Kapital Sosial dalam Perspektif Sosiologik. Jakarta. FISIP UI Press.
Liu, J., Qu, H., Huang, D., Chen, G., Yue, X.,Zhao, X., Liang, Z. 2014. The Role of Sosial Capital in encouraging Residents' pro-environmental Behaviours in Community Based Ecotourism. Tourism Management.

Lopez, A.F., Catarina, R.P., Tiago, N.S., 2012. When Sociable Workers Pay-Off: Can Firms Internalize sosial Capital Eksternalities. Structural Change and Economic Dynamics.

Louhenapessy, M.D., Andaki, J.A., dan Longdong, F.V., 2017. Modal Sosial pada Usaha Penangkapan Ikan dengan Purse Seine di Aertembaga Kota Bitung. AKULTURASI (Jurnal IImiah Agrobisnis Perikanan). Vol. 5 No. 9 (April 2017). Program Studi Agrobisnis Perikanan FPIK UNSRAT. Manado.

Moleong, L.J., 2005. Metode Penelitian Kualitatif, Bandung, Edisi Revisi, Penerbit PT. Remaja Rosdakarya.

Profil Desa, 2017. Profil Desa Tateli Weru Kecamatan Mandolang Kabupaten Minahasa Provinsi Sulawesi Utara.

Putnam, R.D., 1995. Bowling Alone: America's Declining Social Capital. Journal of Democracy: Vol6, No.1

Sudirman, H., dan Mallawa, A., 2012. Teknik Penangkapan Ikan. Rineka Cipta, Jakarta.

Sugiono, 2010. Metode Penelitian Pendidikan Pendekatan Kuantitatif, kualitatif, dan R\&D. Bandung: Alfabeta

Sugiono, 2012. Metode Penelitian Kuantitatif \& RND. Bandung : Alfabeta

Suharto, E., 2007. Modal Sosial dan Kebijakan public. Pdf (secured). 23/6/2007. 1:49PM.

Supardi, M.D., 2006. Metodologi Penelitian. Mataram: Yayasan Cerdas Press.

Walgito, B., 2010. Bimbingan dan Konseling (Studi \& Karir). Yogyakarta: Penerbit CV. Andi Offset. 